\title{
'Southern Jewel': A Self-fertile, Black Muscadine Grape with Fruit Produced on Bunches
}

\author{
Dennis J. Gray ${ }^{1,4}$, Zhijian T. Li ${ }^{2}$, Sadanand A. Dhekney ${ }^{3}$, \\ and Donald L. Hopkins ${ }^{1}$ \\ Mid-Florida Research and Education Center, University of Florida/IFAS, \\ 2725 Binion Road, Apopka, FL 32703-8504
}

Charles A. Sims ${ }^{1}$

Food Science and Human Nutrition, University of Florida/IFAS, P.O. Box 110370, Gainesville, FL 32611-0370

Additional index words. disease resistance, fruit breeding, Vitis rotundifolia

'Southern Jewel' (Vitis rotundifolia Michx.) is a new muscadine grape cultivar being released by the University of Florida that is a high-yielding, disease-resistant, large blackfruited variety. It has the unique characteristic of producing fruit in bunches of six to 12 berries that strongly adhere to the peduncle (Fig. 1). It has an excellent taste and a crunchy texture with a palatable skin, making it well-suited for fresh fruit consumption.

\section{Origin}

'Southern Jewel' originated from a cross between Granny Val, a self-fertile cultivar with large ( 9 to $10 \mathrm{~g}$ ) bronze berries, and DB63 , a self-fertile, black selection with large ( 8 to $9 \mathrm{~g}$ ) berries (Fig. 2). DB3-63 originated from a cross between US42-12B, a black selffertile selection with small ( 3 to $4 \mathrm{~g}$ ) berries, and 'Nesbitt', a self-fertile black cultivar with large (9 $\mathrm{g}$ ) berries. US42-12B originated from a cross between 'Creek', a reddish black female cultivar with small ( $3 \mathrm{~g}$ ) berries, and a hybrid between 'Topsail', a female, bronze cultivar with small (3 g) berries, and NCB619. The origin of NC B619 is unclear because it was variously described as a sibling of 'Topsail' ('Latham' $\times$ 'Burgaw') or a cross between 'Latham' and a seedling from 'Loomis' $\times$ V19 R7 V2.

The original seedling was planted in 1994. Because of its high fruit quality, self-fertile flowers, disease resistance, and unique char-

\footnotetext{
Received for publication 20 Apr. 2009. Accepted for publication 14 May 2009.

This research was supported by the Florida Agricultural Experiment Station, the Florida Grape Grower's Association, and the Florida Department of Agriculture and Consumer Services' Viticulture Trust Fund.

We are indebted to Jeanne Burgess for suggesting the name 'Southern Jewel'.

${ }^{1}$ Professor.

${ }^{2}$ Senior Biological Scientist.

${ }^{3}$ Assistant in Grape Biotechnology.

${ }^{4}$ To whom reprint requests should be addressed; e-maildjg@ufl.edu.
}

acteristic of bearing fruit on bunches, it was propagated for further trial as Fla. AA11-68. It was compared with 11 commercial varieties (black-fruited 'Alachua', 'Delicious', 'Nesbitt', 'Southern Home', and 'Supreme' and bronze-fruited 'Darlene', 'Dixie', 'Fry', 'Pam, 'Summit', and 'Triumph') and eight experimental selections by establishing it in a randomized field trial containing 20 vines of each variety/selection at the Mid-Florida Research and Education Center, Apopka, in 2001 and was evaluated over five fruiting seasons. Vines in the field trial were spaced $3.3 \mathrm{~m}$ apart and trained to a single-wire trellis with two cordons per vine. Fruiting spurs were pruned to four buds in February of each year. Drip irrigation was used and vines were fertilized through broadcast application of $6 \mathrm{~N}-6 \mathrm{P}-6 \mathrm{~K}$ with added micronutrients at a rate of $670 \mathrm{~kg} \cdot \mathrm{ha}^{-1}$ in late March and again in early October.

\section{Description}

'Southern Jewel' has moderate vine vigor and a semirecumbent growth habit with 3- to $6-\mathrm{cm}$ internodes. Leaves average $8 \mathrm{~cm}$ in length and $7 \mathrm{~cm}$ in width, are chordate, with dentate margins, and are apubescent. Leaves' lower surfaces are light green and glabrous, whereas upper surfaces are darker green. Leaves become distinctively rugose compared with other cultivars. Petioles may be shorter or longer than leaf midrib. Tendrils are unbranched, develop opposite of leaves, but are somewhat discontinuous along shoots. New shoots from dormant buds typically produce inflorescences at the third and fourth nodes. Inflorescences are compound panicles composed of eight to 16 flower clusters, each containing five to 25 individual self-fertile (perfect hermaphroditic) flowers. Berries are oval in shape, becoming reddish, then dark purple/black on ripening and $76 \%$ have a dry stem scar. Fruit ripening date varies seasonally but tends to occur in early August at Apopka, $\approx 1$ to 2 weeks earlier than other muscadine varieties and 1 week after 'Delicious', which is another early-ripening variety. Early ripe fruit have a semicrunchy flesh and an edible skin that fragments easily with the flesh. Fruit allowed to ripen further tend to have a softer flesh, become noticeably juicier, but retain an edible skin. Fruit yield is greater; berries are larger and ripen more uniformly than 'Alachua', which also was selected for even-ripening (Mortensen, 2001) (Table 1). Berry texture of 'Southern Jewel' is more firm than but size is similar to that of 'Delicious' and 'Nesbitt'; however, the latter ripens unevenly and has poorer stem scar characteristics. 'Southern Home', a Muscadinia $\times$ Euvitis hybrid, has higher soluble solids and ripens evenly, but 'Southern Jewel' exceeds it in all other characteristics. Supreme, a cultivar with remarkably large berries and excellent fruit characteristics, did not produce an acceptable yield in this vineyard. It is noteworthy that similar results were obtained with 'Supreme' during previous testing at the Central Florida Research and Education Center at Leesburg, FL (data not shown).

Symptoms of Pierce's disease have not been observed in 'Southern Jewel'. Fruits are highly resistant to ripe rot [Colletotrichum gloeosporioides (Penz.) Penz. \& Sacc.], bitter

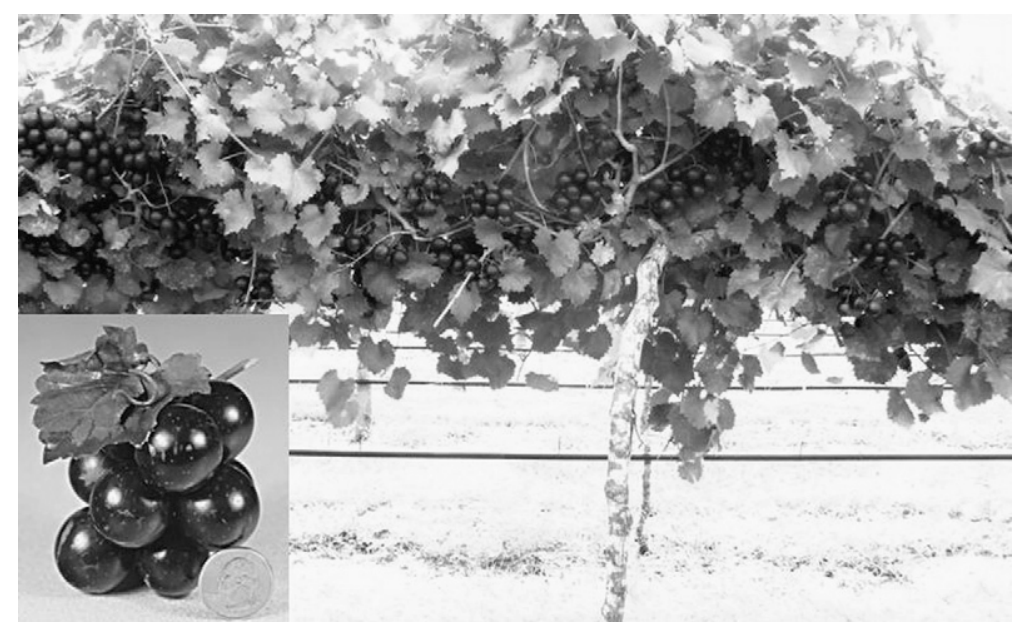

Fig. 1. 'Southern Jewel' muscadine grape. 


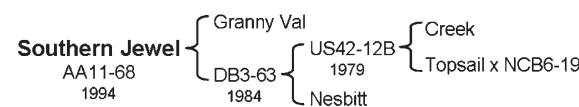

Fig. 2. Pedigree of 'Southern Jewel'.

rot [Greeneria uvicoa (Berk. \& Curt.) Punithalingam], and black rot [Guignardia bidwellii (Ellis) Viala \& Ravaz f. muscadinii] based on evaluations under conditions of low disease maintenance, in which vines received only one application per year of $\mathrm{CuSO} 4$ applied after bud burst.

'Southern Jewel' is being released primarily for fresh fruit consumption. Although untested, its firm texture and adherence of berry to peduncle may make it unsuitable for mechanical harvesting and wine-making.

In taste, texture, and edible skin, 'Southern Jewel' compares favorably with 'Supreme'; however, it is earlier ripening and much more productive at Apopka, albeit smaller in size. Its formation of large berries that adhere to bunches is unique for a muscadine-type grape and should be useful for both fresh fruit and, possibly, processing. Although it grows well

Table 1. Flower type, yield and fruit attributes of 'Southern Jewel' compared with five black muscadines grown for fresh fruit consumption. ${ }^{\mathrm{z}}$

\begin{tabular}{lcccccc}
\hline Cultivar & $\begin{array}{c}\text { Flower } \\
\text { type }\end{array}$ & $\begin{array}{c}\text { Yield/vine } \\
(\mathrm{kg})\end{array}$ & $\begin{array}{c}\text { Fruit with } \\
\text { dry scar }(\%)\end{array}$ & $\begin{array}{c}\text { Berry } \\
\text { wt }(\mathrm{g})\end{array}$ & $\begin{array}{c}\text { Soluble solids } \\
\text { concn }(\%)\end{array}$ & $\begin{array}{c}\text { Type of } \\
\text { ripening }\end{array}$ \\
\hline Southern Jewel & $\mathrm{S}$ & $10.3 \mathrm{~b}$ & $76 \mathrm{~b}$ & $11.0 \mathrm{~b}$ & $15.9 \mathrm{c}$ & Even \\
Delicious & $\mathrm{S}$ & $12.9 \mathrm{a}$ & $90 \mathrm{a}$ & $10.2 \mathrm{~b}$ & $16.9 \mathrm{~b}$ & Even \\
Alachua & $\mathrm{S}$ & $9.4 \mathrm{~b}$ & $75 \mathrm{~b}$ & $7.0 \mathrm{c}$ & $16.8 \mathrm{~b}$ & Even \\
Nesbitt & $\mathrm{S}$ & $13.1 \mathrm{a}$ & $64 \mathrm{c}$ & $9.9 \mathrm{~b}$ & $15.8 \mathrm{c}$ & Uneven \\
Southern Home & $\mathrm{S}$ & $9.2 \mathrm{~b}$ & $58 \mathrm{c}$ & $7.0 \mathrm{c}$ & $18.2 \mathrm{a}$ & Even \\
Supreme & $\mathrm{F}$ & $2.3 \mathrm{c}$ & $96 \mathrm{a}$ & $17.8 \mathrm{a}$ & $17.6 \mathrm{ab}$ & Even \\
\hline
\end{tabular}

${ }^{2}$ Data are the means from 20 vines of each cultivar from the 2007 harvest with 10 berries per vine evaluated for stem scar, weight, and soluble solids. Data were analyzed by general linear modeling with mean separation within columns by Student-Newman-Keul's test $(P=0.05)$.

${ }^{y} \mathrm{~S}=$ self-fertile (perfect hermaphroditic); $\mathrm{F}=$ female (pistillate hermaphroditic), requiring pollenizer.

on deep sandy soils, its adaptation to other regions has not been confirmed.

\section{Availability}

'Southern Jewel' was publically released by the Cultivar Release Committee of the Florida Agricultural Experiment Station, an agricultural research program of the University of Florida's Institute of Food and Agricultural Sciences, on 25 Oct. 2007. Inquiries regarding the availability of 'Southern Jewel' should be directed to Florida Foundation Seed Producers, Inc., P.O. Box 110200, Gainesville, FL 32611-0200. A list of nurseries selling Florida-recommended grape varieties may be obtained from most UF/ IFAS County Extension Offices.

\section{Literature Cited}

Mortensen, J.A. 2001. Cultivars, p. 91-105. In: Basiouny, F.M. and D.G. Himelrick (eds.) Muscadine grape. ASHS Press, Alexandria, VA. 